\title{
ПОЛУЧЕНИЕ ЦИТОТОКСИЧЕСКИХ МОДИФИЦИРОВАННЫХ ОЛОВООРГАНИЧЕСКИХ СОЕДИНЕНИЙ ДЛЯ ПРИМЕНЕНИЯ В ОНКОЛОГИИ
}

\author{
В.В. Голодная, С.И.Тихонов, М.А. Грин \\ МИРЭА - Российский технологический университет, \\ Институт тонких химических технологий им. М.В. Ломоносова, \\ 119571, Россия, Москва, пр-кт Вернадского 86.
}

DOI: 10.19163/MedChemRussia2021-2021-276

E-mail: sonea_9@mail.ru

Наиболее широко исследуемыми среди металлопрепаратов на данный момент являются карбоксилатные комплексы олова (IV), где в качестве лиганда выступают соединения с функциональной группой-СООН, по которой происходит комплексообразование. Оловоорганические карбоксилаты обладают противомикробными, противогрибковыми и противоопухолевыми свойствами, среди многих других. Было доказано, что для данного класса веществ характерно отсутствие перекрестной устойчивости, а также большая эффективность по сравнению с комплексами платины [1].

Ввиду широкого спектра возможных применений соединений на основе олова, в данной работе были рассмотрены, а также получены и охарактеризованы с помощью масс, ИК- и ЯМР-спектроскопии ряд ди- и три- замещенных $\mathrm{Sn-комплексов} \mathrm{на} \mathrm{основе} \mathrm{п-аминобензойной} \mathrm{кислоты} \mathrm{(PABA)} \mathrm{и} \mathrm{защищенного}$ по $\mathrm{NH}_{2}$-функциональным группам лизина (prLys) с потенциальной противоопухолевой активностью. Было исследовано взаимодействие синтезированных соединений с рядом клеточных мишеней с помощью УФ-спектроскопии, а также выполнен молекулярный докинг.

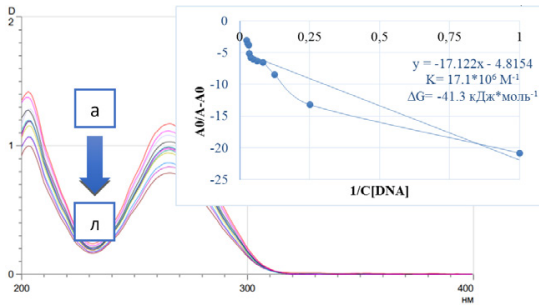

Puc. 1. Пример ЭСП Sn-комплекса (a) и в присутствии (л) 40 мкМ ДНК с шагом 4 мкМ.

Характерные длины волн: $\lambda=203,265$ нм.

\begin{tabular}{|l|l|l|}
\hline Соединение & $\begin{array}{c}\text { Константа } \\
\text { связывания, } \\
106 \text { М-1 }\end{array}$ & $\begin{array}{c}\text { Энергия } \\
\text { Гиббса, } \\
\text { кДжммоль-1 }\end{array}$ \\
\hline PABA-Sn-TMe & 17.1 & -41.3 \\
\hline PABA-Sn-DPh & 2.05 & -36 \\
\hline PABA-Sn-DBu & 56.1 & -44.2 \\
\hline prLys-Sn-TMe & 1.85 & -35.8 \\
\hline prLys-Sn-DPh & 18.5 & -41.5 \\
\hline prLys-Sn-DBu & 54.3 & -44.1 \\
\hline DP-PABA-Sn-TMe & 1.58 & -35.4 \\
\hline DP-Lys-Sn-TMe & 125.5 & -46.2 \\
\hline
\end{tabular}

Работа выполнена при поддержке гранта РФФИ № 19-03-00302.

\section{Литература}

1. Enis Nadia Md Yusof et al, Polyhedrone. 2021, V. 198, 115069. 